\title{
The role of grammatical metaphor in the development of advanced literacy in Spanish as a first, second, and heritage language
}

\author{
Omar Velázquez-Mendoza
}

Correspondence: ov7p@virginia.edu Department of Spanish, Italian, and Portuguese, University of Virginia, Charlottesville, VA 22904, USA

\begin{abstract}
This paper draws some general conclusions from the evidence gathered by two recent analyses, which traced the development of advanced literacy by two undergraduate language learner populations: (1) Humanities students of the National Autonomous University of Mexico for whom Spanish is a native language (L1); and (2) Linguistics students enrolled at the University of California, Davis for whom Spanish is either a heritage $(\mathrm{HL})$ or a second language (L2). Textual scrutiny of student texts extracted from the Corpus del Lenguaje Académico en Español (or CLAE: <www.lenguajeacademico.info>) documents positive trends in the acquisition of ideational grammatical metaphors both in the monolingual, Spanish-only university setting of Mexico, and in the Spanish-English bilingual context of California. In this analysis, I propose that, regardless of the participants' native language(s), learners of Spanish undergo parallel developmental stages within Halliday's model of language acquisition at the advanced level.

Keywords: Systemic functional linguistics; Grammatical metaphor; Language development; Second language acquisition; Heritage language acquisition
\end{abstract}

\section{Introduction}

This study reports on the findings of two recent analyses, which traced the development of advanced literacy by two undergraduate language learner populations: (1) Humanities students of the National Autonomous University of Mexico for whom Spanish is a native language (L1) (Rodríguez 2014); and (2) Linguistics students enrolled at the University of California, Davis for whom Spanish is either a heritage (HL) or a second language (L2) (Velázquez-Mendoza 2014). The studies document that both student populations, the monolingual and the bilingual, gained, though at different rates, a more refined command of Spanish over time. Participants produced more grammatical metaphors-incongruent, multiple-layer ways to represent reality-later in their university studies phase rather than earlier in their participation in the university context. Following Halliday (1993), Colombi (2006), and Ignatieva (2008), a higher frequency of grammatical metaphors in a text-which is relative to the text's genrecorrelates with a more advanced command of the target language. This study holds general implications for the intense and continued debate over whether advanced language learners undergo parallel or dissimilar stages of acquisition as a consequence of

(c) 2015 Velázquez-Mendoza. This is an Open Access article distributed under the terms of the Creative Commons Attribution License (http://creativecommons.org/licenses/by/4.0), which permits unrestricted use, distribution, and reproduction in any medium, provided the original work is properly credited. 
their linguistic background as L1, L2 or HL learners of the language. My findings lend further support to the former view.

\section{Grammatical metaphor and its role in advanced language learning}

Grammatical metaphor is a linguistic resource that allows for the condensation of information by expressing actions, events, attributes, circumstances, and sentential relationships in an abstract, incongruent way. Typical of formal, academic language, this resource contrasts with the more congruent way in which such components of the Grammar of a language are expressed orally. Thus, whereas in ordinary speech one would expect clauses related by hypotaxis or parataxis such as those in $(1)^{1}$ :

(1) Eng. The soldiers attacked the town with guns, and then removed the treasures, Span. Los soldados atacaron el pueblo con armas, y luego removieron los tesoros,

in more formal or academic registers the two sentences linked by the coordinating element and then in (1) would more typically be realized as a single compact sentence composed of main and embedded clauses, as in (2):

(2) Eng. The attack on the town with guns led to the removal of the treasures. Span. El ataque armado del pueblo dio pie al removimiento de los tesoros.

As shown in (1), the congruent way to represent experience in the English clause-as well as the Spanish-is when processes are realized with verbal groups (attacked), participants with nominal groups (the soldiers; the town), associated circumstances as prepositional phrases or adverbial groups (with guns), and logical relationships between clauses through conjunctions (and then).

According to Halliday (1993), Schleppegrell (2004), and Colombi (2006), noncongruent, abstract realizations, such as the grammatically metaphorical expressions of (2), are the single most important feature of advanced literacy. Through this kind of cross-coding, (Colombi (2006): 154) argues, 'actions ... can be talked about in more 'material' terms, as having occurred, as being available for modification and, most importantly, for movement in conceptual space as actors in their own right'. An important secondary effect of the presence of grammatical metaphors in any given message is that its lexical density-the incidence of more content, as opposed to functional, words within a clause-increases. And as a consequence of a higher lexical density, as (Schleppegrell (2004): 72) notes, 'students have to process more ideas per clause'. Thus, the more grammatical metaphors a message bears, the more packed, and objective, the stream of information will be because the agents will generally be removed, as in the attack on the town and the removal of the treasures in (2). Had sentences in (2) been presented in isolation, one would have wondered: 'The attack by whom? The removal by whom?'. As noted earlier, the packing of information that grammatical metaphors allow for is also achieved by combining two or more coordinated clauses, as (1) illustrates, into a single sentence, as in (2). In other words, hypotactic and paratactic constructions, which are typical of oral language, are rather expressed through main and embedded clauses in grammatically metaphorical expressions. 
But why consider constructions such as (2) metaphorical? Because the existence of (at least) two levels of meaning is presupposed in these types of expressions. As stated earlier, both in English and in Spanish the natural way to codify processes like attack and remove, as in (1), is through verbs. But in (2) both of these processes are realized with nouns (attack and removal respectively) rather than with verbs. Thus, the nominal groups the attack and the removal originate from verbs. Therefore, each of these nouns carries at least two levels of meaning in its syntactical/semantic configuration: that of the processes to attack and to remove, on the one hand, and that of the action and result of attacking and removing, on the other. An example of a derivational relationship between a surface form and its corresponding underlying form, which together make up a grammatical metaphor, is given in (3).

a. Surface level: NOUN

b. Underlying level: PROCESS (the) attack 'action and result of attacking'

(to) attack 'process of attacking'

Congruent ways to represent reality are the unmarked way to codify human experience because they are the first set of semiotic structures to be acquired. The alternative, incongruent expressions are thus marked in that, according to (Christie (2002): 47), they 'play with and change the grammar', and following (Halliday (1993): 111), they are acquired later in life. As exemplified in (3), in grammatical metaphors the natural grammatical categories of the lexicon change when abstract, incongruent constructions are derived from their congruent counterparts. And expressions such as the attack and the removal are not simply metaphors in the literary sense, given the (albeit subtle) change in meaning, but rather grammatical metaphors because of the actual switch in grammatical categories in the passage between the underlying language form, that of (3b), and the form corresponding to the surface level, that of (3a).

Systemic Functional Linguistics (Halliday 1973, 1985, 1993, 1994; etc.), a sociosemiotic theory of language, views grammatical metaphor as a linguistic choice that is very unlikely to be acquired outside of the academic or professional setting for a number of reasons. Firstly, generally speaking the input that oral, conversational language with which adults provide children at home tends not to include these types of constructions-at least not when children are addressed directly. Secondly, upon acquiring their first language, children interact with their environment by configuring the world around them in congruent ways first. (Halliday (1993): 109) refers to the natural set of semiotic representations to be acquired earlier in life as 'common sense' structures. Only subsequently will children turn to more abstract and incongruent ways to represent reality, the condition being that they participate actively in formal settings that will provide them with rich amounts of grammatically metaphorical input. In addition, the institutional context will be a forum for individuals to, through their output, experiment with and test the effectiveness of incongruent expressions. The idea is that, by the time human beings start producing grammatical metaphors themselves, the learned or specialist adult community will value them. Colombi and Schleppegrell (2002) refer to the interactive process of participation in formal settings as linguistic acculturation. They write: 'Becoming a member of a community of practice means adopting the 
discourse that is recognized and used by the established members of ... [specialist] communities' (Colombi and Schleppegrell 2002: 7). (Halliday (1993): 111) and (Christie (2002): 46) trace the shift from congruent to incongruent linguistic expressiveness to adolescent writing. As the latter author notes (Christie 2002: 46), '[a]bstractness is not a feature of early writing ... we may [therefore] reasonably assume that a degree of life experience is required before children [can] give expression to it'. To my knowledge, no child has ever been heard to utter sentences such as (2): The attack on the town with guns led to the removal of the treasures.

There are three types of grammatical metaphors: ideational, interpersonal, and logical. As illustrated by (2), in ideational grammatical metaphors it is the elements that construct experiences that are made noncongruent' (Christie 2002: 47). Furthermore, interpersonal grammatical metaphor 'allows for a more explicit or implicit presence of the writer/speaker in ... discourse' (Colombi 2006: 158). Constructions like I think, I believe, I'm convinced, I'm sure, and so on, introduce opinions for which speakers or writers take explicit responsibility. Such incongruent expressions of interpersonality stand in opposition to more congruent forms to convey opinions. An example of a congruent interpersonal metaphor would be the word certainly in the utterance It's certainly colder today than it was yesterday. Although the word certainly may imply 'I think' in this context, such an implication can only represent a hidden stance, as by using certainly, as opposed to I think, the speaker or writer can be less likely to be directly blamed for his or her assessment. A higher level of responsibility would have been attributed to the writer or speaker had he or she employed the metaphorical form $I$ think. Lastly, logical grammatical metaphor refers to 'the condensation of meaning in an incongruent way at the level of ... organization of ... discourse' (Colombi 2006: 157). As stated earlier, the most common way to link ideas is with conjunctions. And when clause, or even sentential links are made in discourse using not conjunctions, but rather verbs or nouns, the latter linguistic choices are considered logical grammatical metaphors, as in the replacement of and then in (1) by led to in its more formal counterpart, example (2).

Now, not all types of grammatical metaphors are employed with the same frequency in language. Following Ravelli (1988), Jones (1990), and Eggins et al. (1993), Colombi (2006) notes that ideational grammatical metaphors compose the vast majority of such structures in Spanish. Within this category, the most frequent subtype of ideational grammatical metaphors is nominalizations, the instantiation of 'processes' and 'attributes' not through verbs and adjectives respectively, as it would have been expected in congruent, 'common sense' language, but rather through nouns.

\section{The study and its methodology}

Given the higher frequency of ideational grammatical metaphors in Spanish, the aim of a recent study that I conducted as part of a larger US-Mexico bi-national project (Ignatieva and Colombi 2014) was the quantification of ideational grammatical metaphors in texts composed by students of the Humanities enrolled at the University of California, Davis. Drawn from the Corpus del Lenguaje Académico en Español (henceforth, $C L A E$ : <www.lenguajeacademico.info $>$ ), all texts comprising my corpus belong to the so-called question-and-answer genre. ${ }^{2}$ The texts were written for an undergraduate applied linguistics course. The total number of participants, for whom Spanish was either an L2 or an HL, was 16. All clauses from all 32 texts, a set of answers for two 
different take-home exams, were scrutinized for ideational grammatical metaphors. The elapsed time from the actual composition of the first exercise to the composition of the second was two months. Every text turned in as a first exam, 16 in total, dealt with the notion of communicative competence; the remaining set, totaling 16 texts, focused on a different topic: the various second language acquisition methodologies.

Ideational grammatical metaphors to be identified in the texts belonged to one of three subtypes: those in which processes were codified as nouns in the prose, as shown in the opposition between (4a, to capture) and (4b, the capturing), those in which processes were instantiated as adjectives, as (5) illustrates (where the form to dominate in (5a) becomes dominant in (5b)), and those in which attributes were remapped as nouns, as in (6) (where the attribute important in (6a) is expressed as importance in (6b)).

(4) a. La cámara fotográfica capta las imágenes.

The camera photographic captures the images

'Photographic cameras capture images'.

b. La captura de las imágenes ... permitió la primera autocrítica física

The capturing of the images ... allowed for the first autocritique physical

objetiva en la historia de la humanidad.

objective in the history of the humanity

'The capture/capturing of images ... allowed for the first objective physical selfcritique in human history'.

(5) a. El partido político domina la sociedad.

The party political dominates the society

'This political party dominates society'.

b. El partido político dominante ... desestabilizó los mercados

The party political dominant ... destabilized the markets

financieros actuales.

financial current

'The dominant political party ... destabilized the current financial markets'.

(6) a. El tema de la salud pública es importante.

The topic of the health public is important

'Public health issues are important'.

b. La importancia del tema de la salud pública reside en que ... éste

The importance of the topic of the health public resides in that ... this

es un derecho humano básico e imprescindible.

is a right human basic and necessary

'The importance of public health resides in that ... it is a basic and necessary

human right'.

Within the framework of the bi-national US-Mexico research cooperation project (Ignatieva and Colombi 2014), the objectives of my study were threefold. First, I wished to identify what might be the prototypical incidence of discursive incongruence that ideational grammatical metaphors allow for in each genre (question-and-answer vs. essay) and in each student population (bilingual vs. 
monolingual). Secondly, I wanted to measure student progress in their academic development in two different points in time as attested to by the frequency of ideational grammatical metaphors in US student texts in Spanish. Thirdly, I sought to investigate how similar or dissimilar linguistic development of students in the bilingual, US university context was in contrast to that of a monolingual Mexican student population in a comparable educational setting.

\section{Results and discussion}

The first issue to be investigated consists of what the prototypical incidence of ideational grammatical metaphors across different academic genres is, namely questionand-answer and essay, and whether or not there may be inherent differences between text genres within such a parameter. Our primary aim here is to contrast two comparable subsets of texts drawn from the CLAE: Mexican vs. Californian question-andanswer documents. This would allow for the identification of how abstract and compact the question-and-answer genre produced in a bilingual (Spanish-English) context is compared to the homologous genre produced in the monolingual-that is, Spanish-only-setting of Mexico.

(Ignatieva (2008): 186) has shown that essays produced in Mexico exhibit a higher incidence of ideational grammatical metaphors, namely, $6.66 \%$, than Mexican questionand-answer texts. The latter genre is characterized for a $1.16 \%$ incidence in Mexico (Ignatieva 2008: 186), and for a $3.06 \%$ in my California corpus (Velázquez-Mendoza 2014: 232). However, in Rodríguez's (2014) study, essays (as opposed to question-andanswer texts) composing his corpus show a much higher average frequency, namely, $20.5 \%$, of grammatical metaphors than the frequencies found by Ignatieva (2008) for her own corpus, even though documents comprising both studies belonged to one and the same genre, the essay, and were composed at the same institution. This discrepancy may be due to actual differences in sample sizes. Rodríguez's (2014) corpus consisted of 30 student essays, whereas Ignatieva's (2008) - given that the US-Mexico bi-national project was at a very early stage in 2008-was composed of only 3 essay texts. Because Rodríguez's (2014) corpus was larger than that of Ignatieva (2008), making it more representative, we will take the former author's percentage average as the prototypical incidence of ideational grammatical metaphors for Mexican student essay texts.

As Fig. 1 illustrates, the Mexican question-and-answer genre appears to be less formal and less compact than its US counterpart. The possibility exists that the different frequencies that Mexican versus US Spanish texts exhibit within the same questionand-answer genre were motivated, at least in part, by the time spent by students in the redaction of their assignments. In Mexico, the question-and-answer documents compiled by Ignatieva (2008) were written in class, which significantly limited the time that students had to condense their information by presenting facts with grammatical metaphors. In my California corpus, on the other hand, question-and-answer texts were written outside of class, as part of a homework assignment. This might explain the higher frequency of ideational grammatical metaphors in US student texts as compared to the Mexican exams of the same genre. Fig. 1 captures the differences in the incidence of linguistic incongruence in question-and-answer documents produced both in Mexico and in California. 


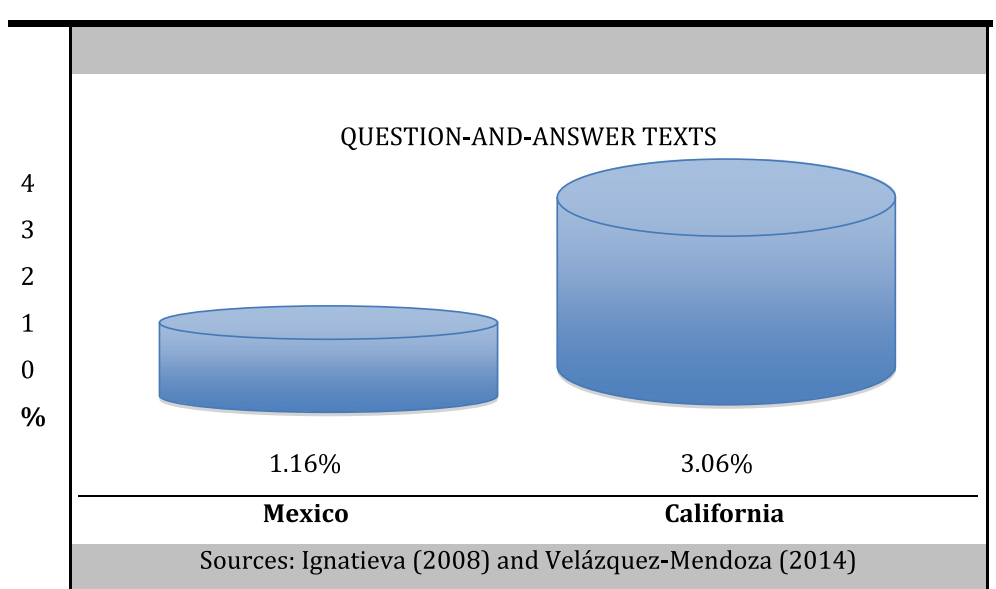

Fig. 1 Incidence of ideational grammatical metaphors in question-and-answer texts produced in Mexico and California

Regarding the first issue to be investigated here, then, the differences captured in Fig. 1 allow us to conclude that question-and-answer texts composed by monolingual Spanish L1 speakers of Mexico can be characterized as less grammatically metaphorical and, therefore, less compact than the set composed by bilingual Spanish L2 and HL speakers of California. The prototypical incidence of ideational grammatical metaphors across genres and academic cultures can be summarized in Table 1.

Regarding the second objective of this study, the measurement of US student progress in two points in time from an advanced literacy perspective, my textual scrutiny yielded the following results.

Over a period of two months, which was the elapsed time between Take 1 and Take 2 in Spanish L2 and HL student texts composed in California, the group of 16 participants of my study produced, overall, more ideational grammatical metaphors in their later set of question-and-answer texts than in their earlier set. The group's percentage at Take 1 was $2.91 \%$ ideational metaphors per total number of words per text; at Take 2, the group's percentage was $3.21 \%$. These data are captured in Fig. 2. What the different incidences of the phenomenon between Take 1 and Take 2 indicate is that the overall increase in the frequency of linguistic incongruence over the two-month period among the bilingual/ heritage population was $0.3 \%$. Therefore, over a period of two months the incidence of metaphorical expressiveness was lower than the prototypical average for texts belonging to the question-and-answer genre in California at Take 1, but it was higher at Take 2.

How do my results compare with those drawn from other studies? In a recent analysis on the frequency of ideational grammatical metaphors in Mexican student texts belonging to the essay genre, Rodríguez (2014) documents an increase of $7 \%$ in a oneyear period among Mexican monolingual students between their first and their second years of study. This is shown in Fig. 2. As noted above, the prototypical incidence of discursive incongruence in texts belonging to the essay genre in Mexico, according to

Table 1 Prototypical frequencies of ideational grammatical metaphors

\begin{tabular}{lll}
\hline Genre & Mexico & US \\
\hline Question-and-answer & $1.16 \%$ (Ignatieva 2008) & $3.06 \%$ (Velázquez-Mendoza 2014) \\
Essay & $20.5 \%$ (Rodríguez 2014) & Results not available \\
\hline
\end{tabular}




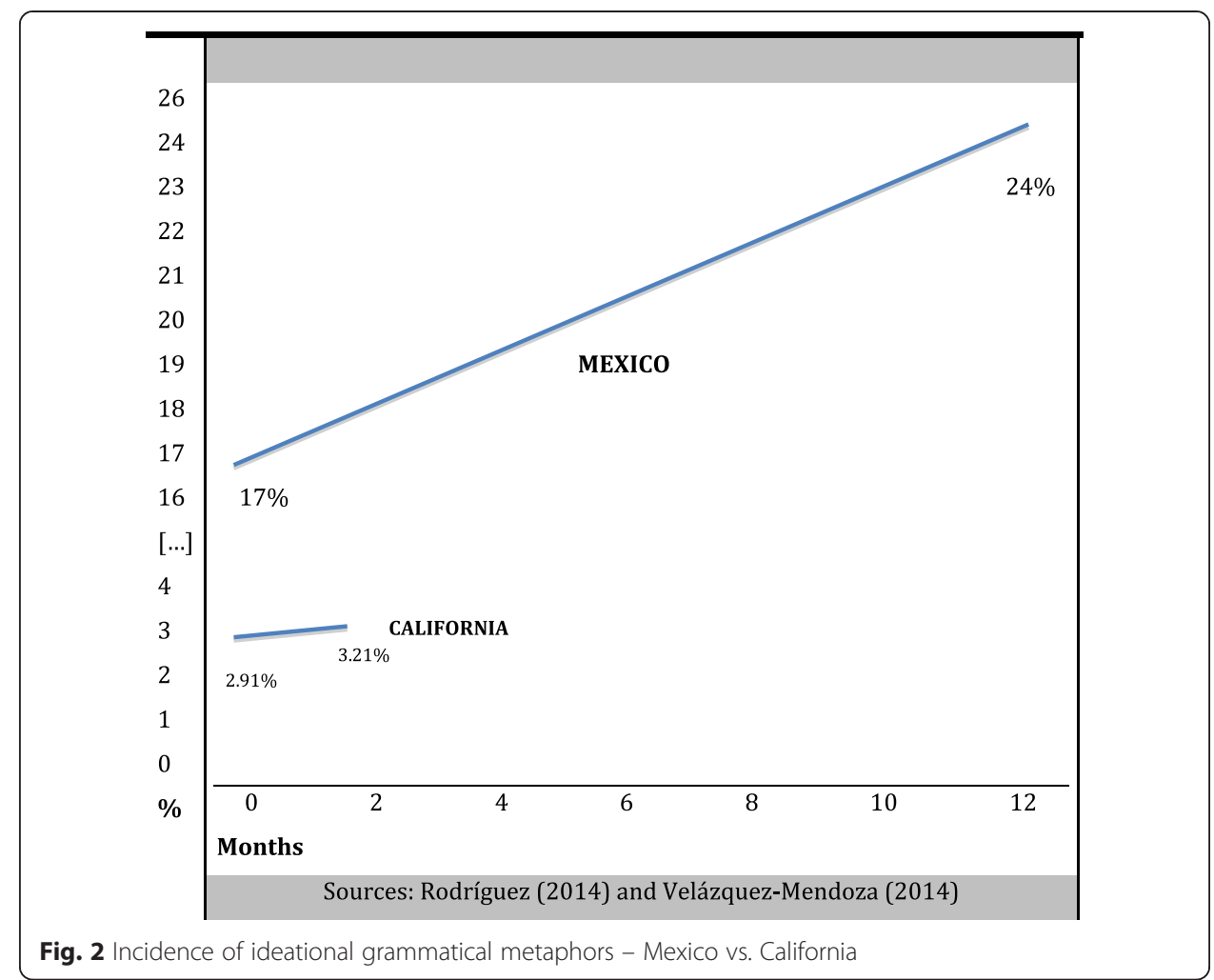

the frequencies found by Rodríguez (2014), is $20.5 \%$. Thus, in a period of one year Mexican essay texts attest to a lower incidence of metaphorical expressiveness than the prototypical average $(20.5 \%)$ at Take $1(17 \%)$ than at Take $2(24 \%)$. The average frequency of linguistic incongruence to which first- and second-year Mexican university student documents attest, as it compares to that of their professors' texts, is captured in Fig. 3.

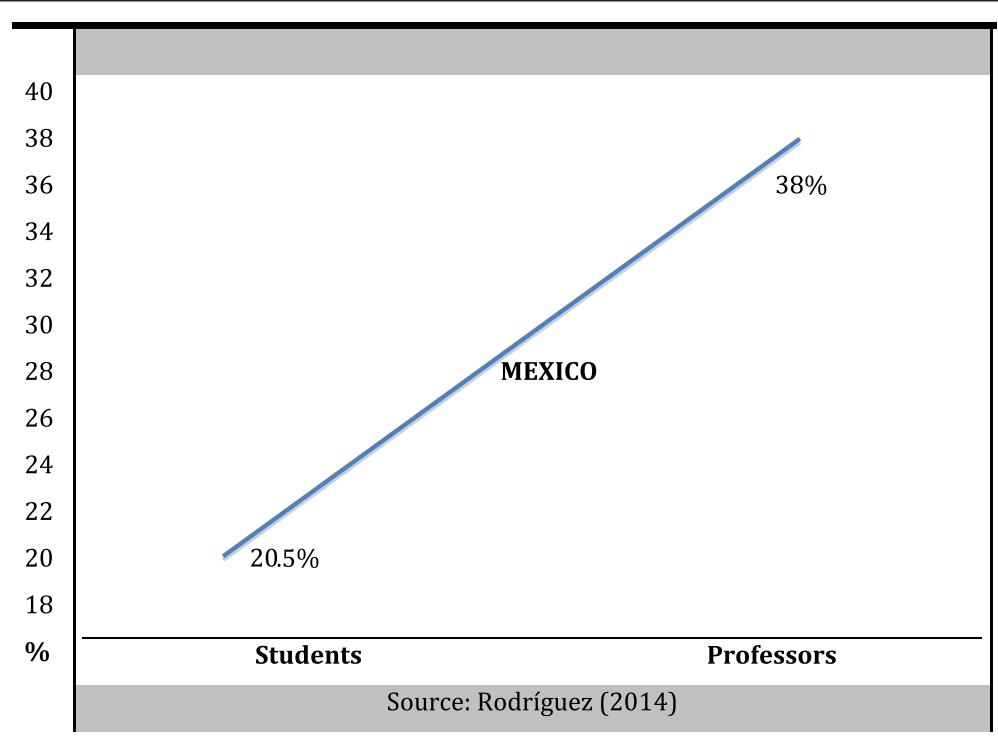

Fig. 3 Differences in the incidence of ideational grammatical metaphors in texts produced by Mexican university students vs. their professors 
Although the percentage increase in the employment of ideational grammatical metaphors in the US student group took place at a slower rate than in its Mexican counterpart, both Rodríguez's (2014) and my data show that, diachronically, in both populations - the bilingual and the monolingual-there was a positive trend in the use of incongruent expressiveness. That is, there was an attempt by the university apprentices to replicate, over time, the input provided to them in their respective academic setting. In fact, as Fig. 4 illustrates, Rodríguez's (2014) study further shows that the more seniority students have in the Mexican university context, the higher the production of grammatical metaphors in their texts will be and, thus, the closer they will move toward the frequencies exhibited in their professors' texts. Expert texts written by such professors-these consisted of published, peer-reviewed articles in Rodríguez's (2014) corpus-contained a $38 \%$ incidence of ideational grammatical metaphors per total number of words per text. Second year university student texts attested to a $24 \%$ frequency, and first year texts to a $17 \%$ frequency. This distribution is captured in Fig. 4.

Now, given the differences found in the incidence of metaphorical expressiveness between US Spanish texts and those produced in Mexico, it is possible that in a monolingual context the acquisition of linguistic incongruence is actually accelerated. This would be a predictable outcome, as it has been well documented that once students have attained an intermediate proficiency level, their command of the target language increases in a monolingual setting. When intermediate language learners participate in study abroad programs, as opposed to when they continue their education in a traditional, non-immersive context, their language development seems to be accelerated. As Rodríguez's (2014) data suggest, this would also apply to Spanish L1 speakers participating in a monolingual academic setting. In a similar vein, it is also possible that the seemingly rapid increase in the use of grammatical metaphors by the Mexican student population, compared to that of the California group, was due to the actual

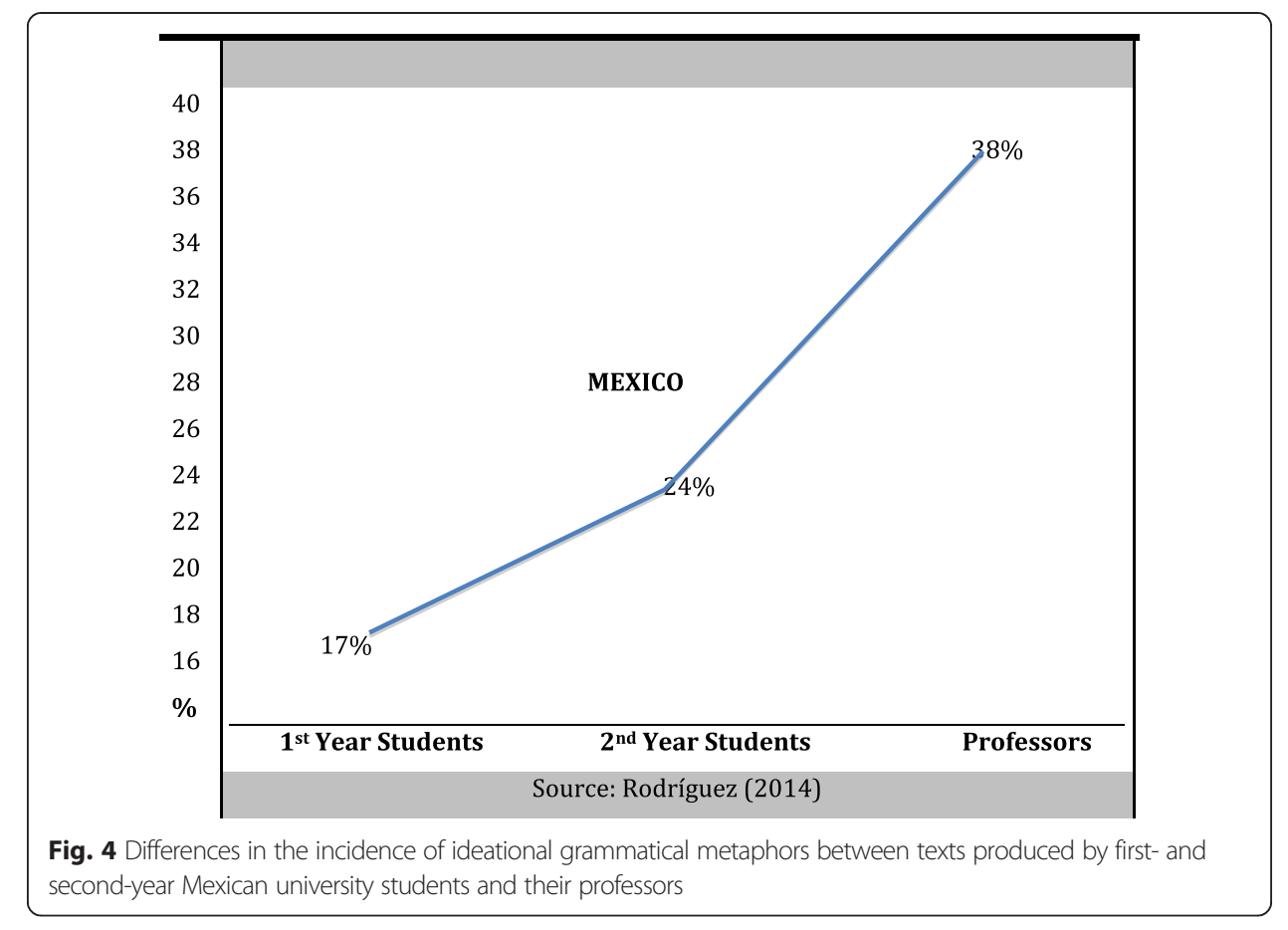


differences in frequencies with which abstract constructions of this type are expected in each genre. Possibly, the higher the expectation for linguistic incongruence within a genre, the harder students will try to emulate such frequency and, therefore, the more recurrent the use of ideational grammatical metaphors will be in their texts. Another possible interpretation for the higher incidence of grammatically metaphorical expressions in the Mexican context, as it compares to the California setting, would point to actual differences in academic culture. That is, the possibility exists that the Mexican university culture favors more highly the use of the grammatical metaphor over its California counterpart. The validity of these assertions is left for future research.

The title of my study is 'The role of grammatical metaphor in the development of advanced literacy in Spanish as a first, second, and heritage language'. So after addressing the first part of the title, namely, what the role of grammatical metaphor in the development of advanced literacy is, allow me now to turn to the second part, or the third issue to be investigated here, which are one and the same. The issue consists of the direction pointed to by the studies discussed so far regarding first versus second and heritage language acquisition at the advanced language level. But before we touch on this matter, let us keep in mind that the first attestations of grammatical metaphors are found in adolescent writing (Halliday 1993; Christie 2002). Other aspects to take into consideration are that grammatical metaphor is usually acquired institutionally (Halliday 1993; Christie 2002; Schleppegrell 2004; Colombi 2006), and that the phenomenon is the single most important linguistic construction to be found in formal registers, in part because it allows for the condensation of language (Halliday 1993; Colombi 2002, 2006; Colombi and Schleppegrell 2002; Christie 2002).

The ongoing debate in the field of applied linguistics regarding the advanced language learner population can be summarized as follows. Given that first and second language acquisition at the so-called novice and intermediate levels differ in many ways-we learn through mostly implicit, effortless mechanisms in the case of first and, arguably, also heritage language acquisition, but through mostly explicit and certainly strenuous processes in the case of second language development-, the assumption has been that, at the advanced level, the same dichotomy must also hold true. This dichotomy would point to different, even opposing, ways to develop advanced literacy. In other words, differences in language development would largely depend on the learner's background as an L1, L2 or HL apprentice. But novel research drawing on pragmatics, discourse analysis, and other functional approaches to language acquisition has questioned the validity of this tenet.

Following Systemic Functional Linguistics, once language learners have surpassed the intermediate proficiency plateau, they seem to follow parallel learning paths in subsequent acquisition stages regardless of the native language or languages involved (Halliday 1985; 1993; Colombi 2000, 2002, 2006; Colombi and Schleppegrell 2002; Christie 2002; Schleppegrell 2004; Achugar and Colombi 2008). Following Halliday (1993: 109), at the intermediate proficiency level English L1 learners are able to 'generalize [and] to construe "common" terms' through congruent, 'common sense' structures. At this stage, the same learners are able to both decode and produce nonmetaphorical (in the grammatical sense) utterances. Such utterances are characterized by low levels of lexical density and a frequent use of coordinated constructions of the and then-type, as shown in (1). Focusing on adolescent English L1 writing in Australia, 
(Christie (2002): 65) notes the absence of grammatical metaphors in 'primary-age writers, [who] produce clauses that offer congruent realizations ... it will be into the secondary years that noncongruent realizations appear'.

For the Spanish HL population, (Colombi (2002): 84) documents that, at Take 1 of her study, bilingual (Spanish-English) learners draw on oral-like structures in their writing, many of which belong to the and then-type of (1), thus 'relying on paratactic and hypotactic clause combinations, familiar to them from spoken discourse'. And at Take 2 of the same study, the interval from Take 1 to Take 2 spanning a nine-month period, the same Spanish HL group 'move[d] ... to more formal registers that use[d] main clauses with embedded clauses' (Colombi 2002: 84). As stated earlier, grammatical metaphors are usually realized through a combination of the latter clauses, as (2) illustrates. Other studies on HL and L2 learners of Spanish also point in the same direction (Colombi 2000, 2006; Achugar and Colombi 2008; among others). For example, in a related longitudinal study on the development of advanced literacy by Spanish L2 and HL learners, Achugar and Colombi (2008) found that, over a nine-month period, the study's participants employed more grammatical metaphors in Take 2 than in Take 1. And because grammatical metaphors are usually realized through a combination of main and embedded clauses, Achugar and Colombi's (2008) Spanish L2 and HL texts attested, conversely, to a decrease in the frequency of hypotactic and paratactic clauses at Take 2. So, overall, learners' linguistic background as first-, second- or even heritage language speakers does not seem to even play a key role in their success at the advanced level. Naturally, there will always be variation in attained proficiencies at the individual level, as no two human beings can develop language-first, second, or heritage-in the same way, at the same rate, or in the same context. But, in spite of these layers of variation, research is showing that all three language populations, Spanish L1, L2, and HL learners, seem to undergo the same acquisition stages once they have surpassed the intermediate plateau.

\section{Conclusion}

Halliday (1993) divides the post-intermediate stages of acquisition into two phases:

(a) The phase of abstraction and metaphor, in which, through the deployment of grammatical metaphors in discourse, both oral and written, 'reality comes to consist of things rather than doing and happening' (Halliday 1993: 111).

(b) The phase of linguistic complementarity, or the sensibility that advanced language learners must develop in order to customize their register according to the formality or informality—or a mid point thereof—of a communicative act.

The studies focusing on grammatical metaphor presented above do indeed indicate that learners, regardless of their native language or languages, must undergo parallel developmental stages within Halliday's (1993) proposed phase (a) of advanced language learning. As Rodríguez's (2014) study focusing on the monolingual context of Mexico demonstrates, Spanish L1 speakers gradually move from the use of more congruent, 'common sense' ways to express reality to the use of ever more abstract language representation forms by increasing, probably in an unconscious manner, the frequency of 
grammatical metaphors in their texts over time. Learners of Spanish as a second- or heritage language in my California study seem to follow the same cognitive route as do their monolingual counterparts-though, as it was discussed earlier, they do so at a slower rate. On a related note, the monolingual Mexican university population must acquire, depending on the text genre in question, an acceptable level of frequency use for the grammatical metaphor, but so, too, does the bilingual population of California. Taken this evidence as a whole, it is more plausible that linguistic acculturation, or the acquisition of linguistic incongruence, takes place in parallel-as opposed to dissimilar-ways for advanced language learners. As (Halliday (1993): 111) himself suggests, 'grammatical abstractness is the key for entering into literacy ... so grammatical metaphor is the key for entering into ... the knowledge that is discipline-based and technical'. The university context imparts just such technical and discipline-based knowledge.

In sum, as the studies presented above report, through linguistic acculturation, those individuals who are exposed to-and participate in-formal, professional or academic settings can gradually master, at different rates and to different degrees, the art of discursive incongruence that the learned community strongly favors when the abstract re-codification of the so very 'congruent' world that surrounds us takes place in advanced language learning. The irony lies in that, if Halliday (1993) is right, those individuals who are eventually finally able to master this art in adulthood will need to learn to silence their newly-attained mastery of language abstraction when participating in informal contexts before they can ultimately reach the state of full linguistic maturity.

\section{Endnotes}

${ }^{1}$ Examples (1) and (2) are drawn-and slightly modified-from Christie (2002: 47).

${ }^{2}$ For more details on the term question-and-answer, see Ignatieva (2008).

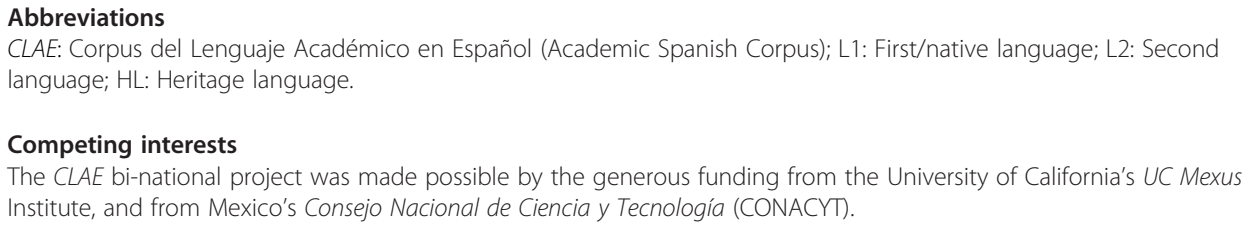

Received: 8 April 2015 Accepted: 21 June 2015

Published online: 28 July 2015

\section{References}

Achugar, M, and MC Colombi. 2008. Systemic functional linguistic explorations into the longitudinal study of advanced capacities: the case of Spanish heritage language learners. In The longitudinal study of advanced second language capacities, ed. L Ortega and H Byrnes, 36-57. London: Routledge.

Christie, F. 2002. The development of abstraction in adolescence in subject English. In Developing advanced literacy in first and second languages: meaning and power, ed. MJ Schleppegrell and MC Colombi, 45-66. New Jersey/ London: Lawrence Erlbaum.

Colombi, MC. 2000. En vías del desarrollo del lenguaje académico en español en hablantes nativos de español en los Estados Unidos. In Research on Spanish in the United States, ed. A Roca, 296-309. Somerville, MA: Cascadilla Press.

Colombi, MC. 2002. Academic language development in Latin students' writing in Spanish. In Developing advanced literacy in first and second languages: meaning with power, ed. MJ Schleppegrell and MC Colombi, 67-86. New Jersey/London: Lawrence Erlbaum.

Colombi, MC. 2006. Grammatical metaphor: academic language development in Latino students in Spanish. In Advanced language learning: the contribution of Halliday and Vygotsky, ed. H Byrnes, 147-153. London: Continuum. 
Colombi, MC, and MJ Schleppegrell. 2002. Theory and practice in the development of advanced literacy. In Developing advanced literacy in first and second languages: meaning and power, ed. MJ Schleppegrell and MC Colombi, 1-19. New Jersey/London: Lawrence Erlbaum.

Eggins, S, P Wignell, and JR Martin. 1993. The discourse of history: distancing the recoverable past. In Register analysis: theory and practice, ed. M Ghadessy, 75-109. London: Pinter.

Halliday, MAK. 1973. Explorations in the functions of language. New York: Elsevier.

Halliday, MAK. 1985. Spoken and written language. Geelong, Australia: Deakin University Press.

Halliday, MAK. 1993. Towards a language-based theory of learning. Linguistics and Education 5: 93-116.

Halliday, MAK. 1994. An introduction to functional grammar. London: Edward Arnold.

Ignatieva, N. 2008. Descripción sistémico-funcional de la escritura académica estudiantil en español. Núcleo 25: 173-195.

Ignatieva, N, and MC Colombi. 2014. CLAE: El lenguaje académico en México y los Estados Unidos: Un análisis sistémico funcional. México, DF: Universidad Nacional Autónoma de México.

Jones, J. 1990. Grammatical metaphor and technicality in academic writing: an exploration of ESL (English as a second language) and NS (native speaker) student texts. In Literacy in social processes, ed. F Christie, 178-198. Deakin University, Australia: Centre for Studies of Language in Education.

Ravelli, L. 1988. Gramatical metaphor: an initial analysis. In Pragmatics, discourse and text: some systemically-inspired approaches, ed. EH Steiner and R Veltman, 133-147. London: Pinter.

Rodríguez, D. 2014. El papel de la metáfora experiencial en la escritura académica. In CLAE: El lenguaje académico en México y los Estados Unidos: Un análisis sistémico funcional, ed. N Ignatieva and MC Colombi, 101-123. México, DF: Universidad Nacional Autónoma de México.

Schleppegrell, MJ. 2004. The language of schooling. Mahwah, New Jersey: Lawrence Erlbaum.

Velázquez-Mendoza, O. 2014. La disciplina de la lingüística y el carácter coloquial del género pregunta-respuesta según el Corpus del Lenguaje Académico en Español (CLAE). In CLAE: El lenguaje académico en México y los Estados Unidos: Un análisis sistémico funcional, ed. N Ignatieva and MC Colombi, 221-237. México, DF: Universidad Nacional Autónoma de México.

\section{Submit your manuscript to a SpringerOpen ${ }^{\circ}$ journal and benefit from:}

- Convenient online submission

- Rigorous peer review

- Immediate publication on acceptance

- Open access: articles freely available online

- High visibility within the field

- Retaining the copyright to your article

Submit your next manuscript at $\boldsymbol{\nabla}$ springeropen.com 